\title{
703 リレー制御系の自励振動を利用した質量測定装置の開発 \\ Mass Measurement System Using the Self-Excited Vibration of a Relay Control System
}

\author{
○正 水野 毅 (埼玉大学), 八百板 純子（理想科学工業）
}

Takeshi MIZUNO, Saitama University, Shimo-Okubo 255, Saitama

Junko YAOITA, Riso Kagaku Corporation

\begin{abstract}
A device for mass measurement under zero-gravity conditions is developed. It uses the self-excited vibration of a feedback system containing on-off relay with a hysteresis. The mass of measurement object is determined from the frequency or time interval measurement of the self-excited vibration.
\end{abstract}

Keywords: Mass measurement, Space engineering, Self-excited vibration, Nonlinear control

\section{1. 粕 言}

著者らは，無重力環境下における質量測定法の一つとし て，ヒステリシス特性を持つリレー制御系の自励振動の周 期から質量を測定する方式を提案し，実験によってその有 効性を検証している(1)。これまでに開発した装置では，渦 電流形センサで変位を検出し，その信号を微分して制御量 である速度を検出していた，しかしながら，使用した渦電 流形センサのリニアリティがそれほど良くないため，あま り高い測定精度が得られなかった，本報では，速度検出に ボイスコイルモータを用いて，質量測定精度の向上を図る。

\section{2. 測定原理}

提案する質量測定方法の原理を図 1 を用いて説明する. 図 1 (a)に示すように, 測定対象物（質量： $m$ ）をアクチュ エータに取付け，往復運動をさせる．測定対象物に作用す るアクチュエータの駆動力 $F(t)$ は, 測定対象物の速度 $v$ に 応じて，正または負の一定值をとるように切換えられる. 切換え時刻は, ヒステリシス特性を持つリレー要素によっ て定められる.すなわち, 全体の構成は, 図 1 (b)に示すよ うなフィードバック制御系となる.

この系の具体的な動作を図 2 を用いて説明する．測定対 象物の速度 $v$ が増加して $v_{0}$ に達すると $F(t)=-F_{0}$, 減少し て $-v_{0}$ に達すると $F(t)=F_{0}$ に切換えられる．自励振動の 周期 $T$ とすると, 次式の関係が成り立つ ${ }^{(1)}$.

$$
m=\frac{F_{0}}{4 v_{0}} T
$$

したがって，自励振動の周期 $T$ を測定すれば，測定対象 物の質量 $m$ は, 式(1)から求められる.

\section{3. 実跧装置}

実験装置の概略を図 3 に示す，2つの VCM の出力軸を カップリングで直結する. 図の右側の VCM はアクチュエ 一タとして測定対象物に駆動力 $F(t)$ を与えるものであり， 左側の VCM は速度センサとして速度を検出するものであ る.板バネは, VCM 可動部が可動範囲の中央（平衡位 置）にあるように拘束するためのものである.

VCM は住友特殊金属株式会社製 LV05-15 で，スト口 一クは $15[\mathrm{~mm}]$, 定格推力は 9.8[N]（いずれもカタログ 值）である．VCM の駆動には電流出力形アンプを用いて いるので，駆動力は，アンプへの指令信号にほとんど遅れ

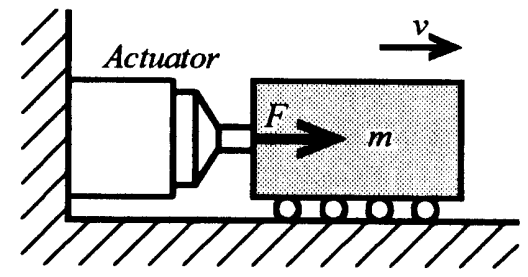

(a) Physical model

relay with hysteresis

mass to be measured

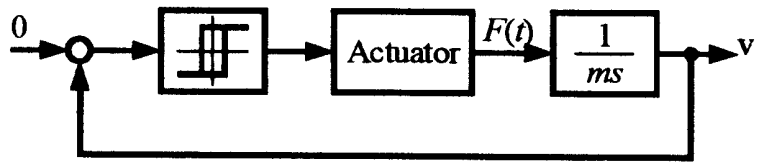

(b) Velocity control system containing a relay with hysteresis

Fig.1 Measurement system

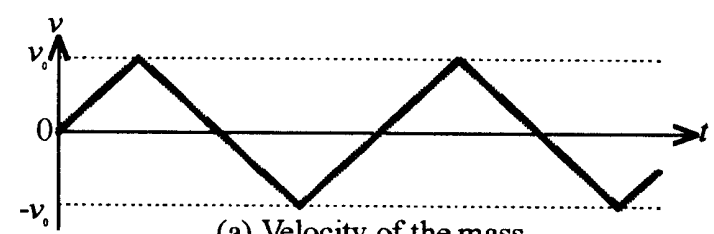

(a) Velocity of the mass

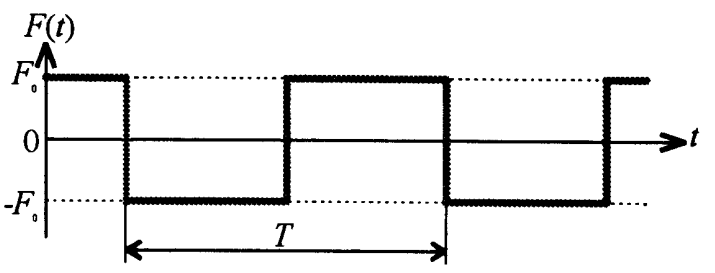

(b) Force acting on the mass

Fig.2 Operation of the measurement system

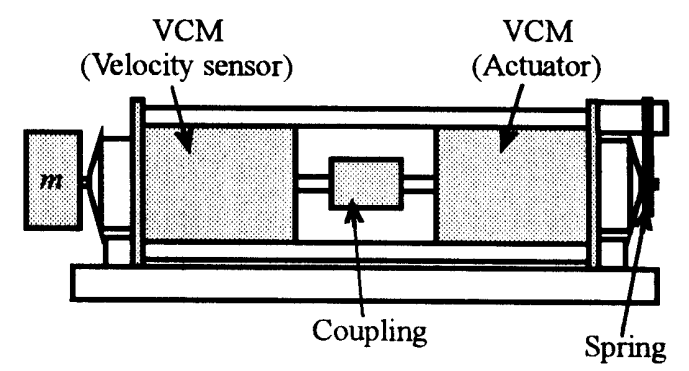

Fig.3 Experimental instrument

日本機械学会関東支部第 8 期総会講演会講演論文集 [’02-3-15,16,船橋市] 
ることなく追従する。

速度センサ用 VCM の逆起電力は，DSP を核とするディ ジタルコントローラに入力される. コントローラでは, そ れから速度を求め, 予め設定したヒステリシス特性が実見 されるように, アンプへの指令信号 $\left( \pm I_{0}\right)$ を出力する. アクチュエータ側 VCM は, 測定原理で説明したように, $\pm F_{0}$ の力を測定対象物に作用させる. ただし，

$$
F_{0}=K_{c} I_{0} \quad\left(K_{c}: \text { 推力係数 }\right)
$$

がである.

\section{4. 実験結果}

質量 $m$ と自励振動の周期 $T$ との関保を調べるために, 10 個の質量（194.5 234.5[g]）に対し，自励振動の周期を 測定した．周期の測定には FFT を用い，32 秒間の平均周 波数から周期を逆算した。測定結果の一例を図 4 に示寸. 図6からわかるように，駆動力 $F_{0}$ が小さく，切換え速度 $v_{0}$ が大きい場合に質量と周期との直線性が良くなる，そこ で, $F_{0}=2.73[\mathrm{~N}], v_{0}=120[\mathrm{~mm} / \mathrm{s}]$ という場合について, 最 小 2 乗法を適用し，周期と質量との関倸を求めると，次式 が得られた。

$$
M=12.787 \times T[\mathrm{~ms}]-107.34[\mathrm{~g}]
$$

つぎに，新たに，196.5 236.5[g]のサンプルに対して， 周期を測定し，その周期を式(3)に代入して，質量の推定 を行った。その結果を図 5 に示す。ここで，真値（Actual mass）としては, 電気天秤（最小分解能 $1[\mathrm{mg}]$ ) で測定し

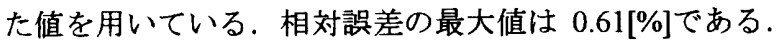
従来の装置を用いて実施した質量測定では，相対誤差の最

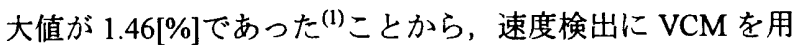
いることによって測定精度が向上できたことが確認された。

\section{5. センサレス化について}

図 3 に示す装置では，質量の駆動と速度の検出に別々の VCM を用いているが，駆動用 VCM のコイルに誘導され る逆起電力を検出すれば, 一つの VCM で駆動と検出を同 時に行うことが可能となる。 このようなセンサレス化は, 宇宙用機器に強く要求される小型化と軽量化に極めて有効 である。.以下では，その原理を説明する。

駆動用 VCM の回路方程式は，次式のようになる.

$$
e=L \frac{d i}{d t}+R i+K_{b} v
$$

ここで, $e: V C M$ コイルの端子電圧, $i:$ コイル電流, $L:$ :イルのインダクタンス, $R$ : コイル抵抗, $K_{b}$ : 逆 起電力係数, $v$ : 可動部の速度である. 式(4)から, コイ ルの端子電圧・電流を検出すれば, 次式から, 速度を求め られることがわかる。

$$
v=\frac{1}{K_{b}}\left(e-L \frac{d i}{d t}-R i\right)
$$

\section{6. 結 言}

オンオフ制御系の自励振動を利用した質量測定装置を試 作し，速度検出に VCM を用いることで質量測定の精度が 向上したことを確認した．現在，センサレス化の実現を試 みている(2).

\section{考文新}

(1) 水野, 高橋 : リレー制御系の自励振動を利用した質量 測定，日本機峨学会2000年度年次大会講演論文集（II）， pp.515-516 (2000).

(2) 八百板: リレー制御系の自励振動を利用した質量測定, 平成12年度埼玉大学工学部卒業論文(2001).

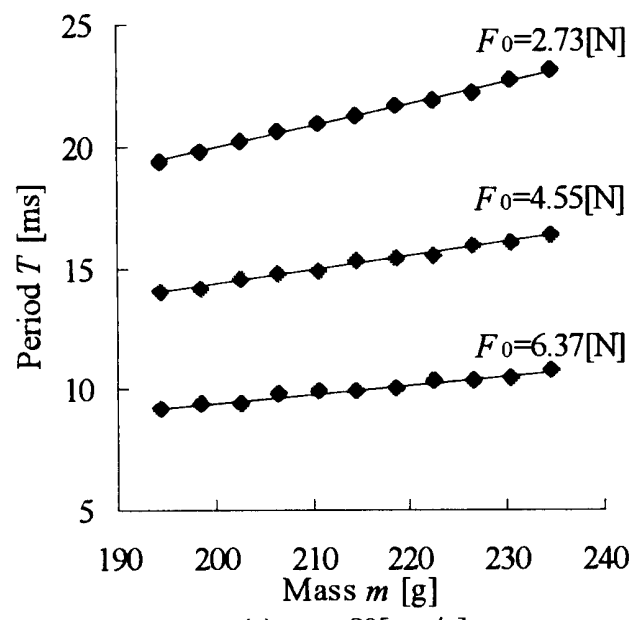

(a) $v_{0}=80[\mathrm{~mm} / \mathrm{s}]$

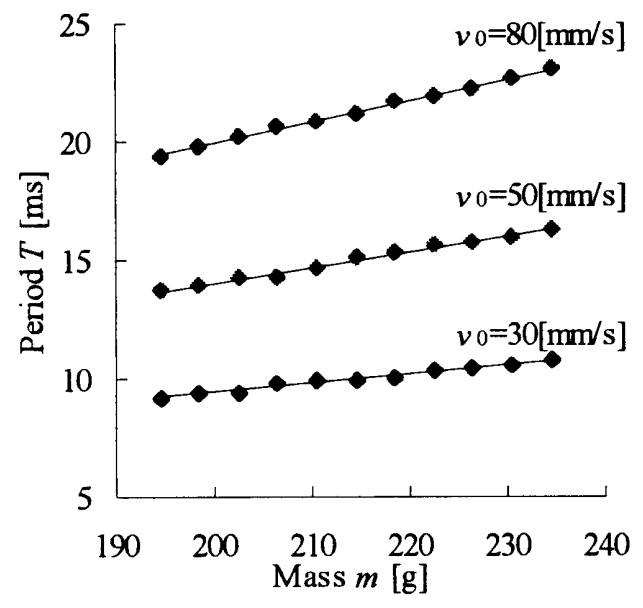

(b) $F_{0}=2.73[\mathrm{~N}]$

Fig.4 Relations between mass and period

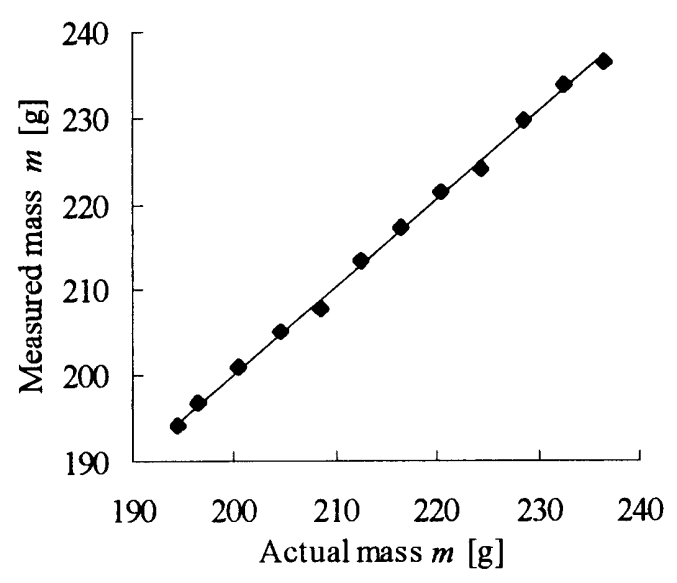

Fig.5 Measurement results 